\title{
Pre-mRNA 3'-End-Processing Factor FIP1
}

National Cancer Institute

\section{Source}

National Cancer Institute. Pre-mRNA 3'-End-Processing Factor FIP1. NCI Thesaurus. Code C97456.

Pre-mRNA 3'-end-processing factor FIP1 (594 aa, $67 \mathrm{kDa}$ ) is encoded by the human FIP1L1 gene. This protein is involved in the polyadenylation of mRNA. 